\title{
KAJIAN PERBEDAAN MINAT MEMBUAT PERENCANAAN KEUANGAN KELUARGA MENURUTTINGKAT PENDIDIKAN DAN PEKERJAAN IBU RUMAH TANGGA DI KOTA PEKANBARU
}

\author{
Lusiawati \\ Fakultas Ekonomi dan Sosial UIN Sultan Syarif Kasim Riau - Pekanbaru \\ E-mail: lusiawati_feuin78@yahoo.com
}

\begin{abstract}
Abstrak
Penelitian ini bertujuan untuk mengetahui perbedaan minat ibu rumah tangga dalam membuat perencanaan keuangan keluarga di Pekanbaru ditinjau dari tingkat pendidikan dan pekerjaannya. Ibu rumah tangga sebagai orang yang sangat berperan dalam menyusun perencanaan keuangan keluarga sangat tepat sebagai sasaran untuk mensosialisasikan pentingnya memiliki perencanaan keuangan keluarga yang baik. Hasil penelitian ini diketahui bahwa berdasarkan tingkat pendidikan responden, ibu rumah tangga yang berpendidikan SMU ke bawah cendrung lebih berminat untuk membuat perencanaan keuangan keluarga daripada ibu rumah tangga yang berpendidikan S1 atau sarjana. Berdasarkan pekerjaan responden, Ibu rumah tangga yang bekerja cendrung lebih berminat untuk membuat perencanaan keuangan keluarga dari pada ibu rumah tangga yang tidak bekerja. Berdasarkan analisis Chi Square diperoleh hasil bahwa tidak terdapat perbedaan minat untuk membuat perencanaan keuangan keluarga antara ibu rumah tangga yang berpendidikan sarjana ke atas dengan ibu rumah tangga yang berpendidikan SMU kebawah. Sementara berdasarkan pekerjaan responden terdapat perbedaan minat untuk membuat perencanaan keuangan keluarga antara ibu rumah tangga yang bekerja dengan ibu rumah tangga yang tidak bekerja.
\end{abstract}

Kata kunci: Perencanaan keuangan keluarga, tingkat pendidikan ibu rumah tangga.

\section{PENDAHULUAN}

Ibu rumah tangga sebagai orang yang sangat berperan dalam menyusun perencanaan keuangan keluarga sangat tepat sebagai sasaran untuk mensosialisasikan pentingnya memiliki perencanaan keuangan keluarga. Sebagaimana kita ketahui bahwa ibu rumah tangga memiliki berbagai macam karakteristik yang berbeda. Tingkat pendidikan, jumlah anak dan pekerjaan ibu rumah tangga sangat mempengaruhi minat dalam menyusun perencanaan keuangan
keluarga.Hasil penelitian yang dilakukan oleh Otoritas Jasa Keuangan (OJK) tahun 2014 yang lalu menyatakan bahwa tingkat literasi sektor jasa keuangan di kalangan ibu rumah tangga dinilai masih rendah yakni 2,13 persen, berdasarkan penelitian yang dilakukan Otoritas Jasa Keuangan dari 8.000 responden di 20 provinsi di Indonesia.

"Khusus untuk ibu rumah tangga, tingkat literasinya masih 2,13 persen dan tingkat utilisasinya 3,37 
$\begin{array}{llr}\text { persen," kata } & \text { Anggota } & \text { Dewan } \\ \text { Komisioner } & \text { Edukasi } & \text { dan } \\ \text { Perlindungan } & \text { Konsumen } & \text { OJK } \\ \text { Kusumaningtuti } & \mathrm{S} \\ \text { Setiono.Berdasarkan } & \text { sensus }\end{array}$ penduduk pada 2010, seluruh penduduk Indonesia berjumlah 237,6 juta jiwa yang terdiri dari 118 juta perempuan, di mana 74 juta di antaranya dikelompokkan sebagai ibu rumah tangga.

Penelitian yang dilakukan oleh Meilyanti, Henny, dan Yohnson dengan judul "Analisis Perbedaan Minat Membuat Perencanaan Keuangan Keluarga Menurut Karakteristik Keluarga Di Surabaya" memberikan gambaran keadaan minat keluarga di Surabaya terhadap perencanaan keuangan. Hasil penelitian tersebut membuktikan bahwa minat keluarga di Surabaya yang berpendidikan tinggi setara $\mathrm{S} 1$ lebih besar dibandingkan keluarga yang berpendidikan menengah setara SMU (Sekolah Menengah Umum) .Jadi faktor pendidikan keuangan sangatpenting agar seseorang tertarik pada perencanaan keuangan.

Penelitian lain yang dilakukan oleh Martha Henn McCormick membahas tentang efektifitas pendidikan pada usia remaja karena remaja paling sering merasakan dampak kompleksitas keuangan keluarga. Studi ini berusaha menggambarkan pendidikan keuangan pada generasi muda saat ini dan memberi arah kedepannya agar dapat membuat keputusan keuangan yang tepat.

Penelitian oleh (Xiao el.al, 2008; Mandell dan Klein, 2009) menyimpulkan bahwa cara terbaik untuk memperbaiki perilaku di usia dewasa adalah dengan cara mengajarkan perilaku yang baik sejak kecil, termasuk perilaku keuangan (financial behavior). Sementara di Indonesia sendiri pendidikan keuangan pribadi (personal finance) masih jarang ditemui baik itu di sekolah dasar sampai perguruan tinggi.

\section{TINJAUAN PUSTAKA}

\section{Pengertian \\ Keuangan \\ Perencanaan}

Menurut Kamus Besar Bahasa Indonesia perencanaan keuangan adalah disiplin manajemen kekayaan yang berlaku dengan kebutuhan unik dan keprihatinan individu masingmasing. Secara sederhana perencanaan keuangan disefenisikan sebagai suatu proses untuk mencapai tujuan hidup melalui pengaturan keuangan yang sesuai. Menurut Bertisch dalam Yohnshon (2004) Financial planning can be defined as the careful preparation and coordination of plans necessary to prepare for fiture financial needs and goals. It is not investment analisys. It involves mapping strategies to achieve your defined goals. Menurut Kapoor (2004) Personal Financial Planning is the process of managing your money to achieve personal economic satisfaction.

Senduk (2009) menyatakan bahwa perencanaan keuangan juga didefinisikan sebagai proses merencanakan keuangan untuk mencapai tujuan-tujuan keuangan jangka pendek maupun jangka panjang.

\section{Pengertian Keluarga Mapan}

Menurut Peck (1993) yang dimaksud dengan keluarga adalah: "Suami-Ayah, istri-ibu dananak- 
anak, dengan kata lain, keluarga inti yang hidup terpisah dari orang lain di tempat tingga lmereka sendiri, dan para anggotanya satu sama lain terikat secara khusus."

Sedangkan Hadisubrata (1990) mengartikan keluarga sebagai unit sosial terkecil di dalam masyarakat, yang terdiri dari ayah, ibu dan anakanak yang belum menikah (nuclear family)Jadi untuk menyamakan persepsi tentang keluarga mapan didalam penulisan ini maka Pengertian keluarga mapan adalah unit sosial terkecil di dalam masyarakat, yang terdiri dari ayah, ibu dan anak-anak yang belum menikah yang mempunyai pemasukan dana lebih besar dari pengeluaran dana secara berkelanjutan.

\section{Keluarga dan Uang}

Kestabilan ekonomi di dalam keluarga merupakan salah satu faktor yang ikut menentukan kebahagian di dalam keluarga, karena penghasilan yang tidak mencukupi kebutuhan hidup dapat merupakan penyebab utama terjadinya pertengkaran di dalam sebuah keluarga. Terjadinya ketidakstabilan dalam perekonomian keluarga bukan saja karena penghasilan yang tidak cukup, tetapi karena keluarga tersebut kurang bijaksana di dalam membelanjakan uang.

Agar ekonomi keluarga stabil maka di dalam keluarga tersebut perlu untuk membuat rencana anggaran belanja, dan mengembangkan sikap-sikap tertentu yang mendukung terwujudnya kestabilan ekonomi keluarga, antara lain keterbukaan antara suami dan istridalam hal keuangan. Sikap lain yang berhubungan dengan pelaksanaan rencanakeuangan keluarga adalah sikap disiplin dalam melaksanakan apa yang telah direncanakan sehingga tidak akan terjadi banyak penyimpangan dari apa yang telahdirencanakan.Latar belakang keluarga, nilai-nilai yang dianut dalam keluarga dan kebudayaan yangdimiliki mempengaruhi cara berpikir seseorang mengenai uang dan pengelolaannya.

Peck (1993) menyatakan bahwa dalam gambaran secara konvensional, keluarga inti diatur berdasarkan pembagian tugas antar pria dan wanita menurut jenis kelamin. Di masyarakat kita umumnya kaum pria (suami) bertugas sebagai pencari nafkah dan memberikan perlindungan di dalam keluarga, sedangkan wanita (ibu) memegang peranan sebagai pengatur kehidupan rumah tangga, baik itu dalam hal mengelola uang yang diberikan suami ataupun dalam mendidik anak-anak.

Membangun Sebuah "Money Saving Mindset" Dalam Keluarga

Menurut Bill dan Mary Toohey (2000) bahwa setiap keluarga harus belajar untuk menyisihkan sekitar 46\% dari pendapatan kotor untuk menabung. Kemampuan menabung memerlukan komitmen dan kadangkadang harus mengubah sikap dan kebiasaan dengan pengharapan mendapatkan kebebasan keuangan.

Pentingnya Perencanaan Keuangan di dalam Keluarga

Pentingnya perencanaan keuangan dalam keluarga bukan hanya bagi keluarga yang berpenghasilan tinggi atau kaya namun juga sangat diperlukan bagi keluarga yang berpenghasilan 
rendah, yang membedakannya adalah dari segi pengalokasian penghasilan tersebut.Menurut Senduk (2009) beberapa alasan mengapa keluarga memerlukan perencanaan keuangan adalah:

1. Adanya tujuan keuangan yang ingin dicapai.

2. Tingginya biaya hidup saat ini.

3. Naiknya biaya hidup dari tahun ketahun.

4. Keadaan perekonomian tidak akan selalu baik.

5. Fisik manusia tidak akan selalu sehat.

6. Banyaknya alternatif produk keuangan.

Fenomena saat ini yang terdengar adalah banyaknya orang yang mengeluh tentang kondisi keuangan yang morat-marit. Dengan sikap hidup yang konsumtif mengakibatkan sesorang memiliki hutang yang jumlahnya melebihi pendapatannya atau bahkan asetnya. Sehingga pengelolaan keuangan yang salah menjadi akar permasalahannya. Apalagi banyak yang tidak memiliki perencanaan keuangan karena perencanaan keuangan merupakan aktivitas mutlak yang harus dilakukan oleh setiap orang . Sehingga hal inilah yang membedakan orang yang mengalami kesulitan likuiditas dengan orang bisa menikmati hidupnya.

\section{Minat Membuat Perencanaan Keuangan Keluarga}

Minat membuat perencanaan keuangan adalah ketertarikan atau perasaan suka yang dimiliki keluarga terhadap perencanaan keuangan yang mendorong keluarga untuk mengetahui, mempelajari lebih dalam dan melakukannya, hingga pada akhirnya keluarga mapan akan tercapai. Dalam kamus psikologi minat diartikan sebagai perasaan yang menyatakan bahwa suatu aktivitas, pekerjaan, atau obyek itu berharga atau berarti bagi individu dan suatu keadaan motivasi yang menuntun tingkah laku menuju satu arah atau sasaran tertentu. Menurut Gregory, "interest is a preference for particular ideas,activities, and objects; value involves the importance or worth attached to those ideas, activitiesand objects". Pernyataan ini dapat diartikan bahwa minat adalah perasaan lebih suka atau tertarik terhadap ide-ide, aktivitas, atau objek; suatu nilai yang penting dan berharga yang terdapat pada ide-ide, aktivitas dan obyekobyek. Sedangkan menurut Winkel minat adalah "Kecenderungan yang menetap dalam subyek untuk merasa tertarik pada bidang atau hal tertentu dan merasa senang berkecimpung dalam bidang itu". Walgito mengatakan bahwa perhatian seseorang terhadap suatua ktivitas ini juga disertai keinginan untuk mengetahui dan mempelajari maupun membuktikan lebih lanjut tentang sesuatu itu. Dan menurut pendapat dari Mappiar bagi seseorang yang memiliki minat yang kuat terhadap sesuatu namun tidak berhasil melaksanakan atau mendapatkan minat tersebut maka besar kemungkinan seseorang tersebut merasakan kekecewaan yang besar.

\section{Literasi Keuangan dan Perencanaan Keuangan}

Menurut buku pedoman Strategi Nasional Literasi Keuangan Indonesia (OJK, 2013), yang dimaksud dengan literasi keuangan 
adalah "Rangkaian proses atau aktivas untuk meningkatkan pengetahuan (knowledge), Keyakinan (Confidence) dan Keterampilan (Skill) konsumen dan masyarakat luas sehingga mereka mampu mengelola keuangan yang lebih baik."

Literasi keuangan juga bermakna bahwa seorang individu yang cakap (literate) adalah seseorang yang memiliki sekumpulan keahlian dan kemampuan yang membuat orang tersebut maтрu memanfaatkan sumber daya yang ada untuk mencapai tujuan. Kecakapan (literacy) merupakan hal penting yang harus dimiliki untuk mencapai tujuan-tujuannya. Literasi keuangan didefinisikan sebagai kemampuan seseorang untuk mendapatkan, memahami dan mengevaluasi informasi yang relevan untuk pengambilan keputusan dengan memahami konsekuensi finansial yang ditimbulkannya.

Temuan Byrne (2007) bahwa pemahaman keuangan yang rendah menyebabkan kesalahan dalam penyusunan rencana keuangan, dan mengakibatkan bias dalam pencapaian kesejahteraan manakala usia tidak produktif lagi. Finansial literasi telah didefinisikan sebagai "kemampuan untuk membuat penilaian informasi dan mengambil tindakan yang efektif mengenai penggunaan saat ini dan masa depan dan pengelolaan uang "(US Dept of Treasury, 2008).

Eitel dan Martin (2009) menjelaskan finansial literasi sangat penting untuk keberhasilan generasi mendatang. Lusardi, (2013), literasi keuangan adalah keterampilan penting bagi pengambilan keputusan dan kesejahteraan selama siklus hidup. Klapper, Lusardi dan Panos, 2012 menyatakan bahwa individu dengan tingkat literasi keuangan yang lebih tinggi secara signifikan lebih mungkin untuk melaporkan lebih banyak pendapatan terpakai pada akhir bulan dan kapasitas pengeluaran yang lebih tinggi. Dan bahwa literasi keuangan yang lebih baik dapat melengkapi individu untuk menghadapi guncangan ekonomi makro.

\section{Financial Literacy dalam Perspektif Islam}

Dalam Literasi Keuangan syariah selain untuk memperluas dan meningkatkan pengetahuan dan pemahaman masyarakat dalam penggunaan produk dan jasa keuangan syariah juga diharapkan dapat mengubah prilaku masyarakat dalam mengelola keuangan secara lebih baik, mampu dan cerdas memilih investasi yang halal dan menguntungkan sesuai dengan syariah. Dengan demikian, masyarakat dapat memperoleh pemahaman mengenai Lembaga Jasa Keuangan syariah serta produk dan jasa keuangan syariah, termasuk fitur, manfaat dan risiko, serta hak dan kewajiban terkait produk dan jasa keuangan syariah. Literasi Keuangan Syariah juga diharapkan mampu mendorong peningkatan pemanfaatan produk dan jasa keuangan yang sesuai dengan kebutuhan masyarakat muslim pada khususnya dan masyarakat Indonesia pada umumnya.

Ketidakmampuan $\begin{array}{r}\text { seseorang } \\ \text { keuangan }\end{array}$
mentam mengelola
berperilaku
boros dalam kehidupannya, padahal
islam melarang untuk berlaku boros.
Sebagaimana firman Allah Ta'ala


dalam surat Al Isra ayat 26-27, "Dan berikanlah kepada keluarga-keluarga yang dekat akan haknya, kepada orang miskin dan orang yang dalam perjalanan dan janganlah kamu menghambur-hamburkan (hartamu) secara boros. Sesungguhnya pemboros-pemboros itu adalah saudara-saudara syaithan dan syaithan itu adalah sangat ingkar kepada Tuhannya." Diperkuat dengan surat Al Furqon ayat 67,'Dan orang-orang yang apabila membelanjakan (harta), mereka tidak berlebihan, dan tidak (pula) kikir, dan adalah (pembelanjaan itu) di tengah-tengah antara yang demikian."

Penegasan ini mensiratkan bahwa seorang muslim harus pandai mengelola uang pribadinya dengan cerdas. Al Qur'an diturunkan 14 abad yang lalu, dan sudah menegaskan pentingnya merencanakan keuangan agar bisa membelanjakan ditengah-tengah antara keduanya (tidak berlebihan/ boros dan kikir).

Al Qur'an telah memberikan peringatan yang tegas tentang harta, dan Rasulullah memberikan kiat praktisnya dalam hadits-hadits shahih, seperti Sahih Muslim No2984, riwayat Abu Dawud dan Nasa'i dan dinilai shahih oleh Ibnu Hibban dan Hakim.

Pendapatan yang dihasilkan tidak sepenuhnya untuk dikonsumsi, namun harus diproduktifkan sebagai modal kerja dan untuk kepentingan ibadah serta kebutuhan sosial lainnya. Hadist-hadits ini menunjukan bahwa pendapatan yang dimiliki tidak hanya untuk dikonsumsi saja, untuk itulah diperlukan pemahaman yang baik tentang perencanaan keuangan, agar pemanfaatannya optimal dan mendapat keberkahan serta bertambah.

\section{HASIL DAN PEMBAHASAN Gambaran Umum Responden}

Berdasarkan hasil survey yang penulis lakukan terhadap 400 orang responden yang tersebar pada 12 kecamatam di kota Pekanbarumaka diperoleh gambaran umum responden berdasarkan tingkat pendidikannya seperti yang terlihat pada tabel berikut:

\section{Tabel 1}

JumlahResponden berdasarkan Tingkat pendidikan

\begin{tabular}{|c|c|}
\hline $\begin{array}{c}\text { Tingkat } \\
\text { Pendidikan } \\
\text { Responden }\end{array}$ & Frekuensi \\
\hline $\begin{array}{c}\text { SMU } \\
\text { kebawah }\end{array}$ & $279(70 \%)$ \\
\hline SMU keatas & $121(30 \%)$ \\
\hline Jumlah & $\mathbf{4 0 0 ( 1 0 0 )}$ \\
\hline
\end{tabular}

Sumber: Data olahan, 2015

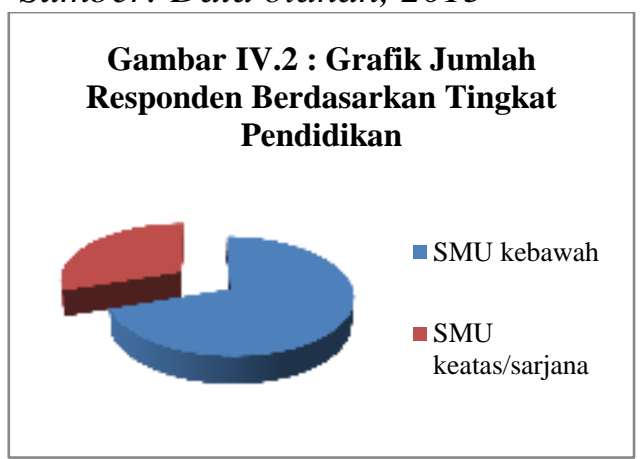

Sumber: Data olahan, 2015

Dari grafik di atas dapat kita ketahui bahwa dari 400 responden sebagian besar atau $70 \%$ ibu rumah tangga memiliki tingkat pendidikan SMU ke bawah dan30\% ibu rumah tangga lainnya berpendidikan diatas SMU atau tingkat Sarjana keatas.

Selanjutnya, dapat diketahui jumlah responden berdasarkan pekerjaan.Dalam hal ini peneliti 
mengidentifikasi data menjadi dua bagian yaitu responden yang bekerja dan yang tidak bekerja.

Tabel 2

Jumlah Responden berdasarkan

Pekerjaan

\begin{tabular}{|l|c|}
\hline $\begin{array}{c}\text { Pekerjaan } \\
\text { Responden }\end{array}$ & Frekuensi \\
\hline $\begin{array}{l}\text { Tidak } \\
\text { Bekerja }\end{array}$ & $167(42 \%)$ \\
\hline Bekerja & $233(58 \%)$ \\
\hline Jumlah & $\begin{array}{c}\mathbf{4 0 0} \\
\mathbf{( 1 0 0 \% )}\end{array}$ \\
\hline
\end{tabular}

Sumber : Data olahan, 2015

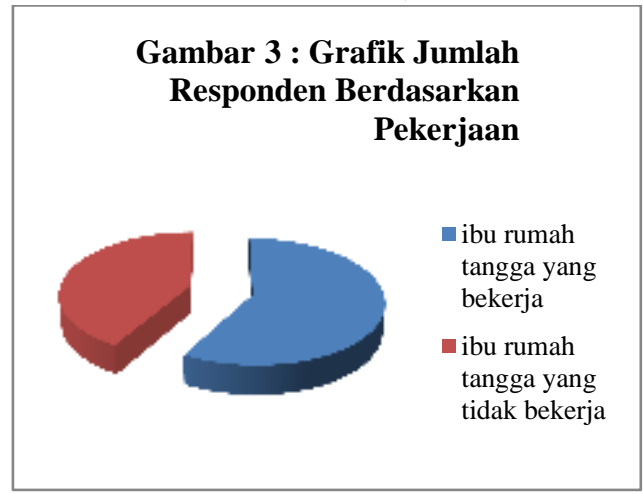

Sumber: Data olahan, 2015

Berdasarkan data diatas dapat kita ketahui bahwa sebagian besar ibu rumah tangga yang menjadi responden dalam penelitian ini adalah ibu rumah tangga yang bekerjayaitu sebanyak 233 orang atau $58 \%$ dan ibu rumah tangga lainnya sebanyak 164 orang atau $42 \%$ tidak memiliki pekerjaan. Hal ini menggambarkan bahwa saat ini ibu rumah tangga di Pekanbaru banyak yang mempunyai pekerjaan di luar rumah seperti menjadi, pegawai swasta, pegawai negeri, berprofesi sebagai guru, dosen, dokter bahkan berwiraswasta dan menjadi pengusaha.

Berdasarkan data yang sudah diperoleh diatas yaitu data tentang tingkatpendidikan dan pekerjaan responden maka untuk melanjutkan analisa dalam penelitian ini dan untuk mengetahui komposisi jumlah responden berdasarkan karakteristik keluarga akan dijelaskan pada tabel berikut.

\section{Tabel 3}

\section{Komposisi Jumlah Responden Berdasarkan Tingkat Pendidikan} Dan Pekerjaan

\begin{tabular}{|l|l|l|l|}
\hline \multirow{2}{*}{$\begin{array}{c}\text { Tingkat } \\
\text { Pendidikan }\end{array}$} & \multicolumn{2}{|c|}{ Pekerjaan } & \multirow{2}{*}{ Total } \\
\cline { 2 - 3 } & $\begin{array}{c}\text { Tidak } \\
\text { Bekerja }\end{array}$ & Bekerja & \\
\hline $\begin{array}{l}\text { SMU } \\
\text { kebawah }\end{array}$ & $\begin{array}{l}157 \\
(94 \%)\end{array}$ & $\begin{array}{l}122 \\
(52 \%)\end{array}$ & $\begin{array}{l}279 \\
(70 \%)\end{array}$ \\
\hline S1 keatas & $10(6 \%)$ & $\begin{array}{l}111 \\
48 \%)\end{array}$ & $\begin{array}{l}121 \\
(30 \%)\end{array}$ \\
\hline Total & $\mathbf{1 6 7}$ & $\mathbf{2 3 3}$ & $\mathbf{4 0 0}$ \\
\hline
\end{tabular}

Sumber: Data olahan, 2015

Berdasarkan tabel di atas diketahui bahwa jumlah ibu rumah tangga yang berpendidikan SMU kebawah yang bekerja sebanyak 122 responden dan yang tidak bekerja sebanyak 157 responden. Sedangkan ibu rumah yang berpendidikan S1 keatas yang memiliki pekerjaan sebanyak 111 responden dan yang tidak memiliki pekerjaan sebanyak 10 responden. Dengan demikian, sebagian besar responden yang pendidikannya SMU ke bawah merupakan ibu rumah tangga yang tidak bekerja. Ibu rumah tangga yang pendidikannya S1 ke atas, hampir seluruhnya merupakan ibu rumah tangga yang bekerja.

Dari data dan uraian di atas maka dapat disimpulkan bahwa gambaran umum karakteristik keluarga di kota Pekanbaru yang ibu rumahtangganya berpendidikan sarjana keatas, rata rata memiliki pekerjaan atau profesi lainnya diluar rumah.Secara umum tingkat ekonomi keluargadengan karakteristik ini cendrung lebih mapan karena 
penghasilan keluarga tentu lebih banyak.

Sedangkan keluarga yang ibu rumah tangganya tidak bekerja artinya hanya berprofesi sebagai ibu rumah tangga adalah ibu-ibu dengan tingkat pendidikan tingkat SMU atau dibawahnya.

Tujuan Penelitian ini adalah untuk mengetahui apakah terdapat perbedaan minat membuat perencanaan keuangan keluarga menurut karakteristik keluarga di kota Pekanbaru. Berdasarkan tujuan tersebut maka untuk mengukur minat responden dalam membuat perencanaan keuangan keluarga dibangunsebuah konstruk dengan empat indikator yaitu rasa ingin tahu terhadap perencanaankeuangan, menyediakan waktu untuk melakukan perencanaan keuangan, kesadaranakanmanfaat perencanaan keuangan, dankecewa jika tidak melakukan perencanaan keuangan.

Setiap indikator diatas dikembangkan menjadi enam pernyataan berdasarkan elemenelemen umum perencanaan keuangan keluarga dengan 5 skala jawaban menurut Likert, jadi total pernyataan dari kuesioner adalah 24 pernyataan dan ditambah dengan 4 pernyataan dengan bentuk pernyataan ya atau tidak.

Dari hasil analisa frekuensi yang telah dilakukan berdasarkan tingkat pendidikan responden diperoleh hasil bahwa ibu rumah tangga yang pendidikannya SMU ke bawah memiliki rasa ingin tahu terhadap perencanaankeuangan sebesar $61,7 \%$ sedangkan yang memiliki pendidikan $\mathrm{S} 1$ ke atas rasa ingin tahu terhadap perencanaankeuangan hanya sebesar
$38,3 \%$. Untuk indikator minat mengenai menyediakan waktu untuk membuat perencanaan keuangan keluarga dari 400 responden yang yang pendidikannya SMU ke bawah sebesar $51,9 \%$, sedangkan yang memiliki pendidikan $\mathrm{S} 1$ ke atas sebesar $48,1 \%$.

Ibu rumah tangga yang yang pendidikannya SMU ke bawah memiliki kesadaran akan manfaat perencanaankeuangan keluarga sebesar $61,7 \%$ sedangkan yang memiliki pendidikan $\mathrm{S} 1$ ke atas hanya sebesar 38,3\%. Merasakan kecewa jika tidak melakukan perencanaan keuangan keluarga bagi ibu rumah tangga yang yang pendidikannya SMU ke bawah sebesar $70 \%$ dan yang memiliki pendidikan S1 ke atas sebesar 30\%.

Dari gambaran di atas diketahui bahwa ibu rumah tangga di Pekanbaru yang yang pendidikannya S1 ke atas cenderung berminat terhadap perencanaan keuangan keluarga dibanding ibu rumah tangga yang pendidikannya SMU ke bawah.

Berasarkan pekerjaan responden diperoleh hasil bahwa ibu rumah tangga yang bekerja memiliki rasa ingin tahu terhadap perencanaankeuangan sebesar $85,1 \%$ sedangkan yang tidak bekerja rasa ingin tahu terhadap perencanaankeuangan hanya sebesar $14,9 \%$. Untuk indikator minat mengenai menyediakan waktu untuk membuat perencanaan keuangan keluarga dari 400 responden yang memiliki pekerjaan sebesar $77,8 \%$, sedangkan yang tidak memiliki pekerjaan hanya sebesar $22,2 \%$. Ibu rumah tangga yang bekerja memiliki kesadaran akan manfaat 
perencanaankeuangan keluarga sebesar $85,1 \%$ sedangkan yang tidak bekerja hanya sebesar 14,9\%. Merasakan kecewa jika tidak melakukan perencanaan keuangan keluarga bagi ibu rumah tangga yang bekerja sebesar $80 \%$ dan yang tidak bekerja sebesar $20 \%$.

Dari gambaran di atas diketahui bahwa ibu rumah tangga di Pekanbaru yang bekerja mempunyai minat yang sangat besar terhadap perencanaan keuangan keluarga dibanding ibu rumah tangga yang tidak bekerja.

Selanjutnya untuk mengetahui perbedaan minat responden dalam membuat perencanaan keuangan keluarga berdasarkan tingkat pendidikan dan pekerjaan dilakukan dengan analisa chi squaredengan hasil bahwa berdasarkan tingkat pendidikan diperoleh nilai chi square hitung untuk rasa ingin tahu adalah sebesar 5,077, menyediakan waktu untuk melakukan perencanaan keuangan adalah sebesar 5,780, kesadaran akan manfaat perencanaan keuangan 5,077 dan nilai chi square hitung untuk rasa kecewa jika tidak melakukan perencanaan keuangan sebesar 6,502.

Dari perolehan nilai chi square hitung untuk semua indikator berdasarkan karakteristik tingkat pendidikan ini terlihat angka yang lebih kecil dari nilai chi square tabel, sehingga dapat disimpulkan bahwa tidak terdapat perbedaan pada indikator minat rasa ingin tahu perencanaankeuangan, menyediakan waktu untuk melakukan perencanaan keuangan, kesadaran akan manfaat perencanaan keuangan, dan kecewa jika tidak melakukan perencanaan keuangan antara ibu rumah tangga yang pendidikan SMU ke bawah dan S1 ke atas.

Hal ini menunjukkan bahwa antara ibu-ibu rumah tangga yang berpendidikan SMU dan ibu rumah tangga yang berpendidikan S1 (sarjana) memiliki minat yang sama besarnya dalam membuat perencanaan keuangan keluarga. Mereka sama-sama mempunyai rasa ingin tahu yang besar, dan sama sama memiliki kesadaran akan manfaat membuat perencanaan keuangan dalam keluarga.

Berdasarkan pekerjaan, nilai chi square untuk rasa ingin tahu adalah sebesar 19,414 >9,488, nilai chi square menyediakan waktu untuk melakukan perencanaan keuangan adalah sebesar 5,093 < 9,488, nilai chi square kesadaran akan manfaat perencanaan keuangan $19,414>$ 9,488 dan nilai chi square kecewa jika tidak melakukan perencanaan keuangan 9,022 < 9,488, sehingga dapat disimpulkan bahwa terdapat perbedaan pada indikator minat rasa ingin tahu terhadap perencanaankeuangan, menyediakan waktu untuk melakukan perencanaan keuangan, kesadaran akan manfaat perencanaan keuangan, dan kecewa jika tidak melakukan perencanaan keuangan antara ibu rumah tangga yang bekerja dan yang tidak bekerja.

Berdasarkan analisis frekwensi ibu rumah tangga yang bekerja cendrung lebih berminat untuk membuat perencanaan keuangan keluarga dibanding ibu rumah tangga yang tidak bekerja.Untuk keluarga dengan ibu bekerja tentu penghasilan atau pendapatan rumah tangga menjadi lebih besar pula yang apabila penghasilan tersebut tidak dikelola dengan baik maka dana 
yang diperoleh tidak termanfaatkan secara efisien dan efektif. Hal ini menunjukkan bahwa dengan penghasilan rumah tangga yang lebih besar kesadaran akan manfaat dan minat untuk membuat perencanaan keuangan juga semakin besar pula.

\section{PENUTUP}

\section{Kesimpulan}

1. Gambaran umun dari karakteristik keluarga di kota Pekanbaru adalah keluarga yang ibu rumahtangganya berpendidikan sarjana keatas, rata rata memiliki pekerjaan atau profesi lainnya diluar rumah. Sedangkan keluarga yang ibu rumah tangganya berpendidikan tingkat SMU atau dibawahnya, rata-rata tidak bekerja artinya hanya berprofesi sebagai ibu rumah tangga

2. Berdasarkan analisis frekuensi ibu rumah tangga yang berpendidikan SMU ke bawah cendrung lebih berminat untuk membuat perencanaan keuangan keluarga daripada ibu rumah tangga yang berpendidikan $\mathrm{S} 1$ atau sarjana.

3. Ibu rumah tangga yang bekerja cendrung lebih berminatuntuk membuat perencanaan keluarga dari pada ibu rumah tangga yang tidak bekerja.

4. Berdasarkananalisis Chi Square diperoleh hasil bahwa tidak terdapat perbedaan minat untuk membuat perencanaan keuangan keluarga antara ibu rumah tangga yang berpendidikan sarjana ke atas dengan ibu rumah tangga yang berpendidikan SMU kebawah.

5. Terdapat perbedaan minat untuk membuat perencanaan keuangan keluarga antara ibu rumah tangga yang bekerja dengan ibu rumah tangga yang tidak bekerja.

\section{DAFTAR PUSTAKA}

Adler H Manurung.2009. Successful Financial Planner A Complete Guide, rasindo, Jakarta.

Annamaria Lusardi, (2008). Household Saving Behavior: The Role of Financial Literacy, Information, and Financial Education Programs (Dartmouth College and NBER).

Brandon, D. P. \& Smith, C. M. 2009. Prospective Teachers' Financial Knowledge and Teaching Self-Efficacy. Journal of Family \& Consumer Sciences Education, 27(1).

Byrne, A. 2007.Employee saving and investment decisions in defined contribution pension plans: survey evidence from the U.K. Financial Services Review 16, 19-40

Chen, H. \& Volpe, R. P. 2002.Gender differences in personal financial literacy among college students.Financial services review11 289-307

Cude, B. J, Lawrence, F. C, Lyons, A. C, Metzger, K, LeJeune, E, Marks, L. \& Machtmes, K. 2006. College Students and Financial Literacy: What They Know and What We Need to Learn. Eastern Family Economics and Resource Management AssociationConference

Departemen Pendidikan Nasional, 2008. Kamus Besar Bahasa Indonesia Edisi 4, PT, 
Gramedia Pustaka Utama, Jakarta.

Danes, S. M. \& Haberman, H. R. 2007.Teen Financial Knowledge, Self-Efficacy, and Behavior: A Gendered View. Financial Counseling and Planning Volume 18, Issue 2

Diana Coben, Margareth Dawes, and Nirmala Lee. 2005. Financial Literacy Education\& Skill of life, Institute of University of London.

Ghozali, I 2007, Aplikasi Analisis Multivariate dengan Program SPSS, Edisi Keempat, Semarang, Badan Penerbit Universitas Diponegoro.

Lawrence Gitman, 2002.Principle of Finance, (11th ed). Prentice Hall, New Jersey

Senduk, Safir. 2009. Seri Perencanaan Keuangan, Mengelola Keuangan Keluarga. PT. Elex Media Komputindo. Jakarta.

Sonia Marcolin \& Anne Abraham. 2006. Financial Literacy Reseach : CurrentLiterature and Future Opportunities, 3rd International Conference of ContemporaryBusiness.

Yohnshon.2004. Peran Universitas di Surabaya dalam Meningkatkan Jumlah Keluarga Mapan di Surabaya. Jurnal Manajemen \& Kewirausahaan Vol. 6, No. 1, Maret 2004: 54 - 71 Ifakultas Ekonomi, Universitas Kristen Petra.

William Tanuwidjaja. 2002. 8 Intisari Kecerdasan Finansial Edisi Revisi, Media Pressindo Jakarta. 